\title{
Sciendo
}

DOI: $10.2478 /$ jolace-2018-0007

\section{Comparative Literature as Educational Means of Understanding and Communication}

\author{
Anna Zelenková \\ Institute of Slavonic Studies of the Academy of Sciences of the Czech Republic \\ zelenkova.anna@centrum.cz
}

\begin{abstract}
The paper explores possibilities of a more intensive use of comparative literature within literary education in which the adoration of national literature prevails together with the abstraction of the concept of world literature. This means putting more emphasis on area and comparative approaches. Emphasising comparative literature may bring in a search and respect for otherness, since it is not connected to any national language and literature, to any concrete tradition and culture, but refers to their variability, with the aim of explaining the contact with the other, which can be close as well as different. More effort should be put especially on the attempt to point to the interconnectedness and mutual influencing. The so-called educational, didactically applied comparatistics is a field of comparative literary studies aimed at overcoming binary, ethnolinguistic opposition of "the national" and "the worldly" in education, and, as far as literary education is concerned, it could become a new methodological stimulus. As a methodological basis of this educational comparative studies is being used the hermeneutic understanding of otherness, though not the interculturally remote one, but a close otherness which exists, for example, in the intertextuality of a particular work emerging within the framework of the "neighbourhood" of common Central European area. What is meant here is, first of all, the so-called innovated imagology, concentrated on the interpretation of images by means of which verbal text renders foreign countries and nations. The overall meaning of imagological impulses can also be seen on the weakening of the opposition of the traditional categories of "national" and "world", as well as in the overcoming of the ideas of some cultures being more developed at the expense of other ones. Applying the area and comparative approach, educational comparative studies may facilitate the dialogue of literature as art also with other spheres, and have integrating as well as didactic function, or develop the feeling of mutuality and the ability to "compare", not only in linguistic and ethnic circumstances, but in the value-contextual ones as well.
\end{abstract}

Key words: comparative studies; educational, didactically applied comparative studies; imagology; category "national" and "world" in literary education

In literary education, there have been a tradition of putting main emphasis on national literature, on its history and individual analyses, to create historical 
consciousness and a receptive horizon of learners through a normatively defined set of texts. They reflect the linking of writers also with the history of a nation anchored in certain state legislative framework. This, many times "defensive" and still surviving concept, typical for small countries of Central and Eastern Europe, is explained to the students as an integral part of national culture involved in the struggle for social and political independence, i.e. in ideological struggles as well. But at the turn of the $20^{\text {th }}$ and $21^{\text {st }}$ century it already lost its educational, didactic subtext, since nowadays the writers may write out of various, including nonideological, reasons, not only because they want "to fight" for their nation. World literature, that is, in fact, great, developed Eurocentric literary "powers," enters individual national "canons" selectively, and often as unreachable models which are only slowly approximated (cf. Neri 1999, p. 250-252). National literature in its so-called "school" understanding has up to now meant a relatively "closed" unit written (most often) in a national "literary" language, emerging at certain time and place with the purpose to affect especially home readers. On the other hand, world literature does not have its specific place, genesis, or a circle of recipients determined in advance, it cannot even define its language - if we do not accept the view that, for example, written in English (i.e. in the currently most preferred language) means "world". The inclusion of this or that text to the pantheon of world literature collides with the lack of clearness as regards contemporary literary terminology, which cannot be transferred to literary education in a simplified form.

One of the possible ways out of the situation, or a kind of compromise between the adoration of national literature and the abstract concept of world literature, could be the departure from strict defining of national literature at the background of the "distant" world literature and the attempt to point to the linkages and mutual influencing. First, this methodological approach would, however, require a greater application not of literary-historical and literary theoretical knowledge (which is often limited by the national context), but the area and comparative approach in literary education. This means to discuss, in the case of classical "national" texts, for example, the possibilities of their "worldliness" (from the aspect of literary and aesthetic quality, which can change), and, in the case of the so called "world works," to more closely determine their relation to a concrete time and space. It is so because comparing, both along the horizontal as well as vertical axis, is one of the basic methodological procedures in social sciences. The comparison of individual phenomena creates conditions for generalising as well as distinguishes essential elements from non-essential. The greater application of comparative procedures in literary education may also bring the search and appreciation of the so-called 
otherness, since also in the "close" national literatures there are agreements as well as differences. Comparative literature is thus not bound to one national language and literature, to a concrete tradition, culture and region, but draws on their variability in unity, and should explain the contact with the other, which can be close, as well as different (cf. Gáfrik \& Zelenka, 2015, p. 79). More emphasis should be paid to the highlighting of mutual interconnectedness and mutual influencing. Taking into account the principle that the text exists so far as it is spatially and temporally perceived at the background of other texts becomes, in comparative literature, one of the conditions of interpretation which explores agreements and differences, relations and "distances" between texts and cultures. The explanation of the comparing of literatures and cultures, understood in this way, results from the fact that the one who compares is positioned „into the middle of things," he/she is a mediator of the process which is carried out through reading, understanding or translations, or, generally speaking, through having pleasure from reading as if from the "culture of hospitality" (the interpreting subject, including the learner, hermeneutically accepts the "participation" of the foreign in oneself).

In our case it is associated with the respecting of unique cultural circumstances of Central Rurope in which national literatures were administratively, linguistically and ethnically interconnected, influencing one another. A significant role was played here by the principle of the struggle for national rights and self-determination within the existence of a large multinational state unit (Habsburg Monarchy), and understanding literary development as a wider, internally arranged and receptively open "interliterary," net into which enter, within the category of time (history of literature, literary history) and the category of space (national literature, Central European area), individual phenomena, works, personalities in mutual relations, not only as parallel representatives of the phenomenon of the "national" (cf. Juvan, 2006, p. 18). In educational practice and the tradition of Central European literary cultures, so far it has been taken into account only to a lesser degree that the category of national literature is, to some extent, relative, since the history of literature in this space of Central Europe does not take place only from the aspect of simple ordering, but is a problematic and discontinuous "story" of different (Slavonic - non-Slavonic) societies, having several parallels, breaking points and "whitespaces". For example, explaining the concept of Slovak literature in schools means paying attention not only to the works of Slovak authors written in Latin, Czech or Hungarian, but it needs to include minority literature as well, i. e. the literature of national minorities which did not originate in the Slovak territory, but outside of it (for example the works of the Lower Lands Slovaks). A 
comparative didactic explanation should - not only in the given case - explain that the complementarity of several literary discourses, for example in the Central European or Mediterranean discourse, coexistence of several languages, poetics and religions, and presence of several ethnic minorities, historically created here a kind of "interliterary net" with a specific communication. In this "net" there appear, in addition to the members of national minorities, also the ethnically linguistically "unclassifiable" authors who, for example, stood on a threshold of two directions, or on the border line of two cultures (c.f. Zelenková, 2009). This also evokes a question of how the circulating themes, artistic traditions, ideas or texts themselves (without regard to the linguistic and ethnic criteria) contributed not only to the understanding of "national" specificities, but also forms, ways and modes of participation in the origin and functioning of this "interliterary net". And thus the didactic understanding and treatment of this process hits upon very many interpretive difficulties, sometimes even misunderstandings or communicational "noise".

A certain possibility for a new, or alternative model of the teaching of literature, its history and a whole complex of literary life, could be a still emerging new discipline labelled as didactics of comparatistics. Its competencies and thematic demarcation (as an independent field) are, in Central European context, being created especially in Polish theoretical discourse. Even though Polish comparative studies does not have such a long and great tradition of comparative study of literature as the Czecho-Slovak one, its development resulted from a strong national philology (domestic Polish studies), which since its beginnings was paying attention, for example, to questions like the aspect of Romanticism in the works of A. Mickiewicz, J. Słowacki, C. Norwid, etc. and further affected various forms of Europen Romanticism. The Czech and Slovak comparative studies were, in fact, developing outside national literature and relied either on Slavonic, or non-Slavonic writings. To the methodology of teaching comparative studies was devoted also the third convention of comparatists, carried out on $30^{\text {th }}-31^{\text {st }}$ March 2016 at Nicolaus Copernicus University in Torun (c.f. Kola \& Wołk, 2016), at which the set aim was not only to evaluate the works of national literature from the viewpoint of interliterariness (c.f. Zelenková, 2008), to interpret them not only from Central European or European perspective, but to analyse how the educationally applied area of comparative studies aims at overcoming the binary, ethno-linguistic opposition of "nationality" and "worldliness" in school practice. The convention confirmed inevitability of a reform of basic school plans as well as higher education curricula in the sense of "linguistically-ethnic and generic-thematic" borders. It highlighted the need of developing such unique reading competencies which 
would lead to contextual reading, i.e. to perceiving a concrete work of national literature at the synchronic and diachronic background of the thematically close texts coming from different literatures, creating aesthetic norm of a European canon. This approach must be conditioned by a conscious weakening of the binary opposition the national - the worldly, that is, of an interpretive difference between a work included only to the system of national literature and a so-called generally known, world text.

Another way towards a change of traditional interpretation, closed into national borders, can be the approximation of educational comparatistics to media studies as well as the search for the intertext and generic transformations, for example, of a concrete character, concrete motif, and so on, in an extensive temporal and spatial framework. What is meant by this is the carrying out of an intertextual communication, when a work of art (or its part) becomes a basis (most often thematic) for the origin of another text. The analysis of the meaning of a literary work thus is done not only on the basis of a receptive impression and experience from the read text, but is created through the intertextual linking as well. This type of interpretive act in the communication process is suitable not only through the so-called project and integrated teaching (see Binterová, Hašek, Karvánková, Pech, \& Petrášková, 2016, p. 14) of contemporary literature and art, that uses, for example, postmodern narrative strategies (citations, parodies, allusions, and so on), but also to the posttext existence, i.e. of the so-called classic work in TV, radio and theatre adaptations. In this case it is ideal if the synchronic and diachronic circle of linking transcends the border of one national literature.

As an example, one can mention a classical work of Slovak literature of the $19^{\text {th }}$ century Faustiáda by Ján Záborsky (1864). It is a grotesque parody of a traditional heroic epic poem, situated into a fictitious Slovak, "noodledom" small city between the Tisza and the Danube. Through the ironizing hyperbole, the author depicts here discords of political life and also creates an interliterary net of reminiscences of Dante, Swift, Rabelais, Cervantes, Milton, Goethe, Kollár, etc. It is possible to identify here two dominant circles of intertextual linking, towards the domestic and world literature. One can find here affirmative allusion to the comedy of the Slovak author from the national revival period Ján Chalupka entitled Kocourkovo, aneb Jen abychom $v$ hanbě nezůstali (1830), which is complemented by a controversial response to the Goethe's Faust's becoming a parodied symbol of tragic break from reality, resulting from the inability to resist the political pressure of the time (see Žilka, 2015, p. 57). A comparatively tuned interpretation with a didactic subtext can thus transcend the "closed off" ethniclinguistic borders and enter the "interliterary net" of European cultural tradition. 
If one tries to sketch out the methodological lines of a still forming didactic comparatistics, its starting point is the hermeneutic understanding of otherness, though not the interculturally distant one, but the close otherness that exists, for example, in the intertextuality of a work originated within the framework of the "neighbourhood" of common Central European area. This is the subject of research especially of the so-called innovated imagology aimed at interpreting the images ("les images") through which foreign countries and nations are captured in a verbal text (see Zelenková, 2016). These images are not an immediate reflection of reality, but have a nature of myths, stereotypes and communication models which manifest themselves as certain ideological schemes, especially the relations between neighbours. It is neither, however, a psychological study of the national character, nor a sociological bearing of reception responses. The basic issue in imagological interpretation of a literary texts is not what qualities this or that national literature has, but what subjective qualities are attributed to individual texts and which interest ethnic and social groups benefit from the individual functions of this text. From imagological perspective, the texts are not divided based on the aesthetic or linguistic aspect, but on the importance and topicality of the theme, and especially on the reception effect on the circle of recipients. The educational aspect may be seen in the fact that the history of images and ideas of what the individuals and groups think of themselves, how they perceive and value one another, are relative and often do not correspond with reality. They are just certain "metadescriptions", which, however, influence (not only) the neighbouring nations.

Imagological impulses are also used by educational comparatistics. The beginnings of imagology originated in the German-French discourse, i.e. between the two nations whose rivalry was during the centuries influencing not only the Central European, but world history as well. However, in the 1950s and 1960s Konrad Adenauer and Charles de Gaulle began, after the WW II, creating symbolic foundations of the unified Europe, and their previous competition was to be transferred from the political-ideological sphere to the sphere of artistic and intellectual discourse, to the art of language and culture (Sinopoli 2009: 262). A common group of German and French philologists, historians and literary scholars was selecting works in both literatures form the $18^{\text {th }}$ to $20^{\text {th }}$ century and was trying to capture the themes of mutual "seeing each other", that is, how French characters and institutions are depicted in German texts, and vice versa. After several years, already first results brought a surprising finding - the "images" which were over the centuries influencing political confrontation (on one side Germans as a symbol of militancy and barbarism, on the other one the careless and emotional French, etc.) are in fact long forming stereotypes which, 
however, have no bearing on reality. In the Central European territory, the imagological method of educational comparatistics can also explain the SlavonicSlavonic relations (Russian x Poles, Czechs x Slovaks, etc.) or Slavonic-nonSlavonic ones (Czechs x Germans, Slovaks x Hungarians, etc.). In all the cases, they are "neighbours" with specific relations, not only within a mutuality, but non-mutuality as well. The imagological focus of educational comparatistics can thus be used at schools as well, e.g. in the study of national proverbs, phraseological expressions or anecdotes reflecting the supposed "character forming" qualities of individual ethnic and social groups or individuals, etc. For example, the analysis of Jewish humour created by non-Jews (especially Germans) can, in some cases, reveal either the hidden or even open elements of antisemitism and xenophobia, or point out to ethnic stereotypes which draw on a generally accepted idea of Jews, leading, for example, to the physical (big nose, prominent ears) or inner characteristics (stinginess, greediness, etc.).

At the beginning of the $21^{\text {st }}$ century, with regard to the globalisation of the ideologically non-bipolar Europe within the European Union, human sciences, including comparative literary studies, began concentrating on the search for "a new language" of its "unity", i.e. searching also whether there exists something as "European" literature, or a consciousness of literary belonging to European values based on the ancient legacy and Christian civilisation. From this point of view, the easiest and fastest way could be the creation of generically, chronologically or thematically interconnected anthological books of reference and translations which would be based on the principle of geographicallycultural area (i.e. a kind of virtual poly-literary system), and which would, despite the multilinguality of individual territories and texts, lead to the creation of a specific interliterary community (cf Durišin, 1995, p. 73). This aim of the methodology of teaching comparatistics could possibly lead to the creation of a kind of common European reading book functioning at schools, especially in higher grades in parallel language mutations. The entire suppressing of auditive approach would probably be not real, and a certain counterbalance could be represented here by a selection of extracts from individual national literatures according to a parity aesthetic key set in advance, e.g. in the number of three to five texts, but irrespective of the measure of aesthetic "development" or "greatness" of a national literature. Thus, in general without regard to the existing "framing" to an idea of some kind of accepted European pantheon of literary texts. This should be gradually formed by this anthology into a dynamic and flexible phenomenon. One must be aware of a danger of the extent of time (from ancient literature up to the postmodernism of $21^{\text {st }}$ century) and the multilingual nature of the texts, which should be balanced by the quality of 
translations and their selection, which, in turn, should give preference in individual national literatures both to the authors on the threshold of cultures with a variable linguistic code, and the cosmopolitan authors drawing on common European civilisation tradition. It is understandable, and I am aware of it, that the "de-nationalising" realisation of the task and the problematic nature of the selection and creation of such anthology would run into several technical and translatological difficulties resulting from the variability and great number of texts. But despite this, the so far only possible attempt to include a European reading book into the schools of European nations could become one of the tasks of the methodologists of comparatistics.

As mentioned above, the sense of the use of comparatistics in literary education may be seen in the weakening of the opposition of traditional categories of the "national" and the "world", in fact, it is the overcoming of national ideas of the dominance or development level of some cultures at the expense of other ones. A non-ideological study of certain "images" incessantly circulating among the nations of Central Europe, as it is understood by the imagological orientation of comparative study of literature, relativizes the normative understanding of a nation and national language in literary education. The educational compartistics may use the area and comparative approach in the explanation of the history of Central Europe to make possible a "dialogue" of literature as art also with other spheres, for example, with political or economic sphere (integration function), and may have an education aspect as well, since criticism of nationalism leads to a greater mutual tolerance and understanding (didactic function). At the same time, it also provides an instruction for alternative reading of generally known reader book texts, through a possible revealing of hidden layers in a text (aesthetic and axiological function). And finally, it may also develop a consciousness fellowship and an ability to "compare" (ethical-moral function), i.e. to perceive reality around oneself not only in linguistically-ethnic, but value-contextual relations.

\section{References}

Bitnerová, H., Hašek, R., Karvánková, P., Pech, P., \& Petrášková, V. (2016). Klíčové kompetence a mezipředmětové vztahy. České Budějovice: Jihočeská univerzita v Českých Budějovicích.

Ďurišin, D. (1995). Teória medziliterárneho procesu I. Bratislava: Ústav svetovej literatúry SAV.

Gáfrik, R. \& Zelenka, M. (2010). Literárna komparatistika. In Milukáš, R. et al. (Eds.), Podoby literárnej vedy. Teórie - Metódy - Smery (pp. 74 - 92). Bratislava: Veda. 
Juvan, M. (2006). On the Tate of the "Great" Genre. In Dolinar, D. \& Juvan, M. (Eds.), Writing Literary History. Selected Perspective from Central Europe (pp. 17-46). Frankfurt am Main: Peter Lang Verlag.

Kola, A. \& Wołk, M. (2016). Między kryzysem a rozwojem. Ogólnopolskie sympozjum dydaktyków komparatystyki, Toruń, 30-31 marca 2016 roku. Porównania, 18, 349-355.

Neri, F. (1999). La Weltliteratur e il canone letterario. In Introduzione alla letteratura comparata. A cura di Armando Gnisci. Milano: Bruno Mondadori.

Sinopoli, F. (2009). Od vnútrokultúrneho porovnávania k medzikultúrnemu. (transl. Pavol Koprda). In Koprda, P. et al. (Ed.), Medziliterárny process VI. Teória medziliterárnosti 20. storočia I. (pp. 260-280). Nitra: FF UKF.

Zelenková, A (2016). On the Imagological Reflection of the Tinker Topos in the Librettos of J. K. Chmelenský and K. Želenský. Porównania, 19, 32- 40.

Zelenková, A. (2009). Medzi vzájomnost'ou a nevzájomnost'ou. Sondy do československých a slovensko-českých literárnych vzt'ahov. Praha \& Nitra: Slovanský ústav AV ČR, v. v. i. \& Univerzita Konštantína Filozofa.

Zelenková, A. (2008). Slovacko-češskaja vzaimnost' i nevzaimnost' (K metodologii izučenija slovacko-češskych otnošenij). In Pospíšil, I. \& Zelenka, M. (Eds.), Česká slavistika 2008 (pp. 357-371). Brno \& Praha: Česká asociace slavistů Literárněvědná společnost, pobočka Praha - ACADEMICUS.

Zelenková, A. (2008). Východiskové tézy k problematike slovensko-českej vzájomnosti a nevzájomnosti. In Pospíšil, I. (Ed.), Slavistika dnes (pp. 241248). Brno: Česká asociace slavistů \& Ústav slavistiky FF MU 2008.

Žilka, T. (2015). Faustovský mýtus a jeho podoby. In Žilka, T., Od intertextuality $k$ intermedialite (pp. 49-60). Nitra: FSŠ UKF.

\section{Contact}

doc. PhDr. Anna Zelenková, Ph.D.

Slovanský ústav AV ČR, v. v. i.

Valentinská 1, 11000 Praha 1

Česká republika

zelenkova.anna@centrum.cz 